\title{
A Study on Thermo-Mechanical Behavior of AA5754 Alloy (Tread and Plain Sheet) Produced by Twin-Roll Casting
}

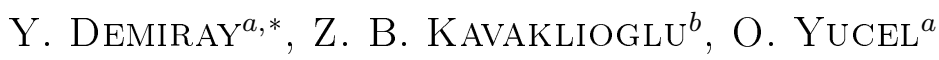 \\ ${ }^{a}$ Istanbul Technical University, Metallurgical and Materials Eng. Dept., 34469 Maslak, Istanbul, Turkey \\ ${ }^{b}$ University of Applied Sciences, Schmalkalden, Germany
}

\begin{abstract}
Aluminum alloy AA5754 is used for many technical and industrial applications. Twin roll casting is unique among the casting processes in that it is a combined "solidification/deformation" technique. The simultaneous solidification and hot rolling produces characteristic microstructure with a fine cell size and intermetallic particle distribution with some residual structure. In the study, first AA5754 alloy (tread and plain sheet) strips were fabricated by using a twin-roll caster equipped with water-cooled steel-rolls. To reduce the thickness of the strip, cold rolling process was applied until strip thickness got $3 \mathrm{~mm}$. After homogenization step the strips were cut in to smaller specimens and annealed at $260^{\circ} \mathrm{C}, 285^{\circ} \mathrm{C}, 310^{\circ} \mathrm{C}, 340{ }^{\circ} \mathrm{C}, 370{ }^{\circ} \mathrm{C}, 400{ }^{\circ} \mathrm{C}, 430{ }^{\circ} \mathrm{C}, 460^{\circ} \mathrm{C}, 490{ }^{\circ} \mathrm{C}$, $520^{\circ} \mathrm{C}$ for 3 hours to obtain the desired temper conditions. Mechanical properties were investigated after processes. Tensile, hardness and bending tests were applied to monitor the effect of annealing after cold rolling process.
\end{abstract}

DOI: $10.12693 /$ APhysPolA.127.1097

PACS: 81.05.Bx Metals, semimetals, and alloys

\section{Introduction}

Twin roll strip casting has advantageous features, such as low running cost, low energy cost, space saving, low equipment costs. Besides these features it also has some disadvantages, which are inferior mechanical properties and low casting speed $[1,2]$. Twin-roll casting allows metal strip to be produced directly from molten metal instead of direct-chill (DC) casting and subsequent hotroll milling processing. This results in a relatively low running and equipment cost. Cooling rate of twin-roll casting is higher then that of other casting methods, but in some aluminum alloys, the higher cooling rate helps mechanical properties to get improved. The technique is not suitable for other aluminum alloys with wide freezing range. Another disadvantages of the technique is its low productivity, because of low casting speed of the roll caster $[3,4]$. To manufacture finished aluminum products, twin roll casting is followed by cold rolling process. As a effect of cold rolling process, there occurs strain hardening. At the end of cold rolling it is observed that yield strength of sheet increases and the ductility decreases $[5,6]$. To obtain the desired mechanical properties and temper conditions, cold rolled byproduct is annealed. In this study, aluminum plates which are produced by twin roll casting were cold rolled to $4.60,3.80$ and $3.00 \mathrm{~mm}$ thickness and annealed at different temperatures to have different tempers assigned by EN.

\section{Experimental}

In our industrial scale study, $6.00 \mathrm{~mm}$ thickness and $1300 \mathrm{~mm}$ width of AA5754 aluminum alloy (chemical compositions is given in Table I) is cast using twin roll casting technology. Chemical analysis of product was determined by Bruker Quatron 6 Colombus spectrometer.

Chemical composition of the investigated cast alloy (wt.\%) [7].

TABLE I

\begin{tabular}{c|c|c|c|c|c|c|c|c}
\hline \hline Alloy / Element & $\mathrm{Mg}$ & $\mathrm{Mn}$ & $\mathrm{Si}$ & $\mathrm{Fe}$ & $\mathrm{Zn}$ & $\mathrm{Ti}$ & $\mathrm{Cu}$ & $\mathrm{Al}$ \\
\hline $\begin{array}{c}\text { AA5754 } \\
\text { (EN AW-Al-Mg } 3)\end{array}$ & $2.6-3.6$ & 0.50 & 0.40 & 0.40 & 0.20 & 0.15 & 0.10 & Balance \\
5754 Product & 2.95 & 0.45 & 0.30 & 0.50 & 0.06 & 0.02 & 0.03 & Balance
\end{tabular}

As homogenization step, $6.00 \mathrm{~mm}$ thickness roll was annealed at $520^{\circ} \mathrm{C}$ for 8 hours. After homogenization step, the strip was cold rolled to $4.60 \mathrm{~mm}$ thickness (23.3\% deformation) by using cold rolling mill process. This $4.60 \mathrm{~mm}$ strip was cold rolled to $3.80 \mathrm{~mm}$ strip with deformation of $17.3 \%$. $3.80 \mathrm{~mm}$ thickness strip was cold rolled to $3.00 \mathrm{~mm}$ tread and $3.00 \mathrm{~mm}$ plain sheets with deformation of $26.7 \%$. At the end of twin roll casting and cold rolling processes, plain sheets which have thickness of $4.60 \mathrm{~mm}, 3.80 \mathrm{~mm}, 3.00 \mathrm{~mm}$ and tread sheet which has a thickness of $3.00 \mathrm{~mm}$ were obtained. The conditions and specifications of twin roll caster and rolling mill are given in Table II. Each sheets were then cut into 10 pieces which have dimensions $300 \mathrm{~mm} \times 300 \mathrm{~mm}$. Annealing process was applied to this new small sized sheets. Temperature range was selected from $260^{\circ} \mathrm{C}$ to $520^{\circ} \mathrm{C}$. Sheets were annealed at $260^{\circ} \mathrm{C}, 285^{\circ} \mathrm{C}, 310^{\circ} \mathrm{C}$, $340{ }^{\circ} \mathrm{C}, 370{ }^{\circ} \mathrm{C}, 400{ }^{\circ} \mathrm{C}, 430{ }^{\circ} \mathrm{C}, 460{ }^{\circ} \mathrm{C}, 490{ }^{\circ} \mathrm{C}, 520^{\circ} \mathrm{C}$ for 3 hours. Laboratory scale electric resistance furnace was used for annealing process. 
The conditions and specifications of Twin-Roll Caster and Cold Rolling.

\begin{tabular}{lrlr}
\hline \hline \multicolumn{2}{c}{$\begin{array}{r}\text { The Conditions and Specifications of } \\
\text { Twin-roll Caster }\end{array}$} & \multicolumn{2}{c}{ The Conditions and Specifications of } \\
Cold Rolling
\end{tabular}

\section{Mechanical testing}

Tensile Test: Tensile tests were conducted to evaluate the strength and ductility of the annealed AA5754 alloy. Samples were prepared as mentioned in standard ISO 6892-1. Zwick Z050 model testing machine was used [8].

Hardness Test: Hardness measurements were made to observe the annealing response. Mirror polished cross sections specimens were prepared and Leica VM HT hardness test equipment was used. Load and loading time were selected as $1000 \mathrm{~g}$ and $12 \mathrm{~s}$ respectively.

Bending Test: Three point bending tests were applied by using Autograph AGS- Jthree point bending test equipment. Velocity was selected as $5 \mathrm{~mm} \mathrm{~min}^{-1}$. Test was achieved according to BS EN ISO 7438:2005, metallic materials bend test [9]. The bending test was carried on until cracks formed at bending point. Angles that occurred after the bending test were compared.

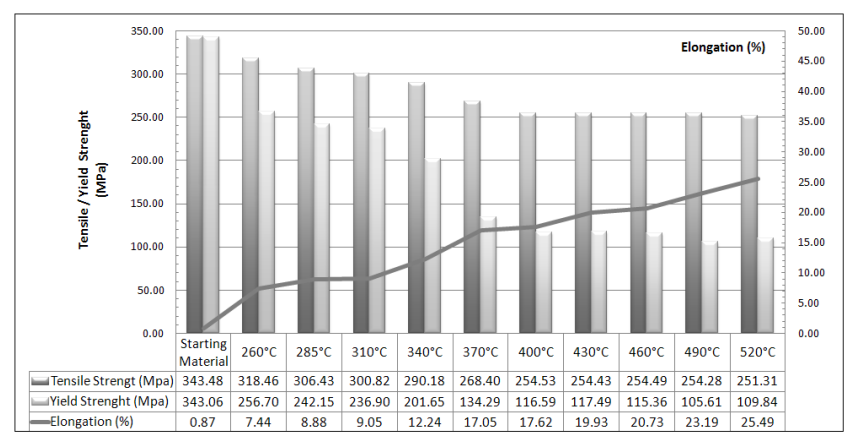

Fig. 1. Tensile strength, yield strength and elongation (\%) of $3.00 \mathrm{~mm}$ plain sheets.

\section{Results and discussions}

The tensile strength, yield strength and elongation (\%) properties depend on annealing temperature. In Fig. 1 mechanical test results of the $3.00 \mathrm{~mm}$ plain sheet are given as an example. Mechanical test results of $4.60 \mathrm{~mm}$, $3.80 \mathrm{~mm}$ and $3.00 \mathrm{~mm}$ tread sheets show the same tendency as the results displayed in Fig 1. It is seen that elongation (\%) increases as a result of decreasing yield stress.
According to the result of tensile tests and EN 485-2 and EN 1386 standards, it is seen that different temper conditions are reached at different annealing temperatures [10, 11]. H12 and H14 tempers are gained for all plain samples at $285^{\circ} \mathrm{C}$. H12 temper is reached for all plain samples at $310^{\circ} \mathrm{C}$ and $340^{\circ} \mathrm{C}$. $\mathrm{H} 22$ and $\mathrm{H} 32$ tempers are gained for all plain samples at $370^{\circ} \mathrm{C}$. H244 temper is gained for tread sample at $340^{\circ} \mathrm{C}$. Above $400{ }^{\circ} \mathrm{C}$ only H111 temper is gained in both plain and tread sheets samples $[10,11]$.

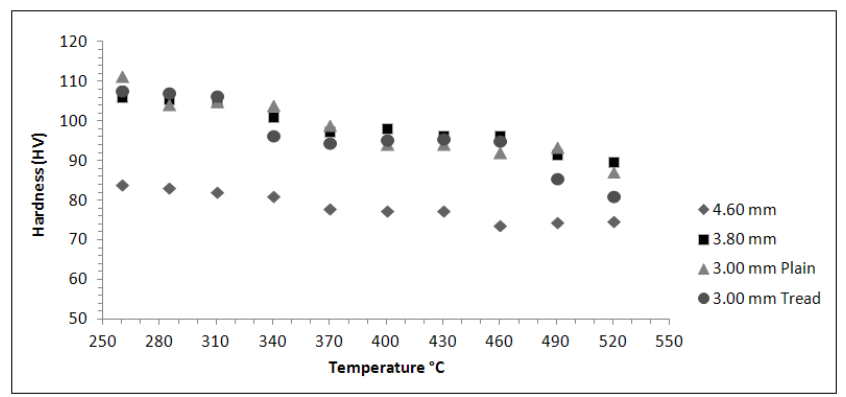

Fig. 2. The hardness values of the samples.

It is seen that after cold rolling process the hardness of sheets increased as expected. The maximum hardness was measured as $111.3 \mathrm{HV}$ on $3.00 \mathrm{~mm}$ plain sheet after 3 hours of annealing at $260^{\circ} \mathrm{C}$. After annealing process it is seen that hardness of sheets tended to decrease. The minimum hardness is measured as $73.8 \mathrm{HV}$ on $4.60 \mathrm{~mm}$ plain sheet after 3 hours of annealing at $460{ }^{\circ} \mathrm{C}$. The results of hardness test are in agreement with tensile properties. As hardness values have decreased, elongation (\%) has increased as well. The results are given in Fig. 2.

Bending properties of the starting material and the annealed samples of $4.60 \mathrm{~mm}, 3.80 \mathrm{~mm}, 3.00 \mathrm{~mm}$ plain and $3.00 \mathrm{~mm}$ tread sheets are shown in Figure 3a, 3b, 3c and $3 \mathrm{~d}$ respectively. Starting material has more brittle properties because of the cold rolling. It is seen that after annealing, ductility of AA5754 alloy has increased because of recrystallization [5]. The angle at the point of bending has increased as a result of the increased ductility and the decreased yield strength. No cracks were observed on samples of $3.80 \mathrm{~mm}$ annealed at $520^{\circ} \mathrm{C}, 3.00 \mathrm{~mm}$ 


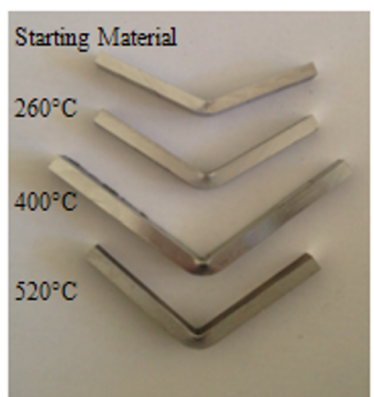

(a) $4.60 \mathrm{~mm}$ plain

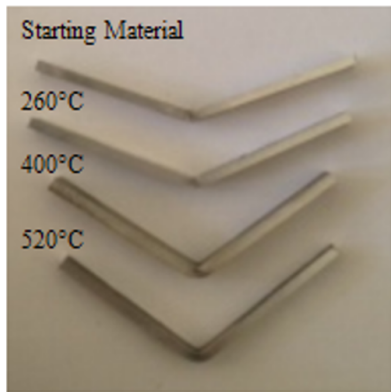

(c) $3.00 \mathrm{~mm}$ plain

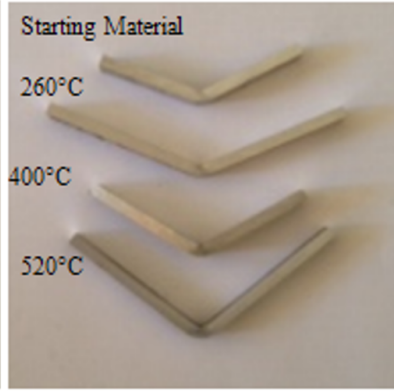

(b) $3.80 \mathrm{~mm}$ plain

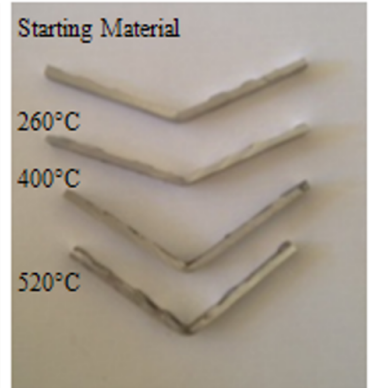

(d) $3.00 \mathrm{~mm}$ tread

Fig. 3. Macroscopic photograph of the starting material and of the cold rolled and annealed samples.

plain annealed at $520^{\circ} \mathrm{C}$ and $3.00 \mathrm{~mm}$ tread annealed at $520^{\circ} \mathrm{C}$.

\section{References}

[1] M. Yun, D.J. Monagham, X. Yang, J. Jang, D.V. Edmonds, J.D. Hunt, R. Cook, P.M. Thomas, Cast Met. 4, 108 (1991).

[2] D.V. Edmonds, J.D. Hunt, D.J. Monagham, X. Yang, M. Yun, Proceedings of the Extraction Refining and Fabrication of Light Metals, CIM, Ottawa, 257 (1991).

[3] T. Haga, K. Tkahashi, M. Ikawaan, H. Watari, J. Mater. Process. Tech. 153-154, 42 (2004).

[4] T. Haga, S. Suzuki, J. Mater. Process. Tech. 143144, 895 (2003).

[5] D. Askeland, P. Fulay, W.J. Wright, The Science and Engineering of Materials, Cengage Learning, 297 2010.

[6] M. Tajally, Z. Huda, Z.M. Masjuki, J. Appl. Sci. 9, 3888 (2009).

[7] EN 573-3, Aluminum and aluminum alloys - Chemical Composition and Form of Wrought Products, 2007.

[8] ISO 6892-1, Metallic Materials Tensile Test, 2009.

[9] BS EN ISO 7438:2005, Metallic materials Bend test, 2005.

[10] EN 485-2, Aluminum and Aluminum Alloys. Sheet, Strip and Plate - Part 2: Mechanical Properties, 2008.

[11] EN 1386, Aluminum and Aluminum Alloys - Tread Plate Specifications, 2007. 